\title{
A FEBRASGO e as Ações Voltadas para a Promoção da Saúde
}

\begin{abstract}
A Federação Brasileira das Sociedades de Obstetrícia e Ginecologia além de seu papel fundamental de promover a atualização e universalização de conhecimentos entre seus associados e de lutar por tabelas que os contemple com honorários justos, reconhece e que assumir seu papel social. Nenhuma sociedade científica é uma Ilha. O estímulo a aplicação dos avanços técnicos, diagnósticos e terapêuticos, em prol do bem comum, também é meta que nos cabe alcançar. Em nossos corpos associativos está a elite da Ginecologia e Obstetrícia de nosso País. Suas pesquisas e descobertas são para melhorar e resolver os problemas de saúde que afligem a mulher. Por isso, a Febrasgo está de braços abertos para , como órgão consultivo, assessorar todo e qualquer programa que vise a melhoria da qualidade da assistência prestada à saúde da mulher brasileira.
\end{abstract}

\section{A Diretoria}

